\title{
(5)

\section{Bløtvevsemfysem, pneumomediastinum og luft i spinalkanalen ved diabetisk ketoacidose}

KORT KASUISTIKK

\section{VIKTORIA VEDELER AMUNDSEN}

E-post: viktoriavamundsen@gmail.com

Barneavdelingen

Sykehuset Innlandet - Elverum

Viktoria Vedeler Amundsen er lege i spesialisering i barnesykdommer.

Forfatteren har fylt ut ICMJ-skjemaet og oppgir ingen interessekonflikter.

\section{RUT HEIDI HAANDE}

Avdeling for bildediagnostikk

Sykehuset Innlandet - Elverum

Rut Heidi Haande er spesialist i radiologi og avdelingsoverlege.

Forfatteren har fylt ut ICMJ-skjemaet og oppgir ingen interessekonflikter.

\section{THOMAS CHR. RISOM OLSEN}

Anestesiavdelingen

Sykehuset Innlandet - Elverum

Thomas Chr. Risom Olsen er barneanestesiolog og assisterende avdelingsoverlege.

Forfatteren har fylt ut ICMJ-skjemaet og oppgir ingen interessekonflikter.

Diabetisk ketoacidose er en kjent komplikasjon til nyoppstått diabetes mellitus. I denne kasuistikken presenterer vi et tilfelle med uvanlige komplikasjoner.

En tidligere frisk gutt i begynnelsen av tenårene hadde kastet opp og vært slapp en ukes tid. Han hadde også hatt hyppig vannlatning. Da han ble økende sløv, oppsøkte familien legevakten. Legevaktlegen mistenkte diabetisk ketoacidose, og et umålelig høyt blodsukker støttet diagnosen.

Etter undersøkelsen på legevakten hovnet gutten plutselig opp på halsen og høyre side av ansiktet. Det var ikke tilhørende ømhet, rødme/varme eller påvirkede luftveier. Hevelsen ble tolket som subkutant emfysem.

Gutten ble innlagt ved nærmeste barneavdeling. Arteriell blodgass var forenelig med alvorlig ketoacidose (arteriell $\mathrm{pH}$ under 7,1 eller bikarbonat $<5 \mathrm{mmol} / \mathrm{l}(1)$ ), med $\mathrm{pH}$ 7,oo6 (7,36-7,44) og bikarbonat $2,7 \mathrm{mmol} / \mathrm{l}(22,0-26,0 \mathrm{mmol} / \mathrm{l})$. Blodsukkeret var $41 \mathrm{mmol} / \mathrm{l}$ (4-6 mmol/l). Væskebehandling etter retningslinjer fra pediatrisk akuttveileder (1) ble 
startet og pågikk under transport.

Da han ankom intensivavdelingen, svarte han på tiltale, men fremsto som forvirret og dehydrert. Han hadde rask, dyp respirasjon med frekvens 40/min (14-19/min), puls 130/min (55-95/min), stabilt blodtrykk og normal oksygensaturasjon $\left(\mathrm{SpO}_{2}\right)(>95 \%)$. Det var uttalt subkutant emfysem over øvre thorax, halsen og høyre side av ansiktet. Han klarte ikke å åpne høyre øye på grunn av hevelse i øyelokk. Det var sidelike lungelyder, men hjertelydene var vanskelige å høre. Røntgen thorax (figur 1) tolket på stuen viste luft i mediastinum, bløtvevsemfysem og sannsynlig pneumothorax på venstre side.

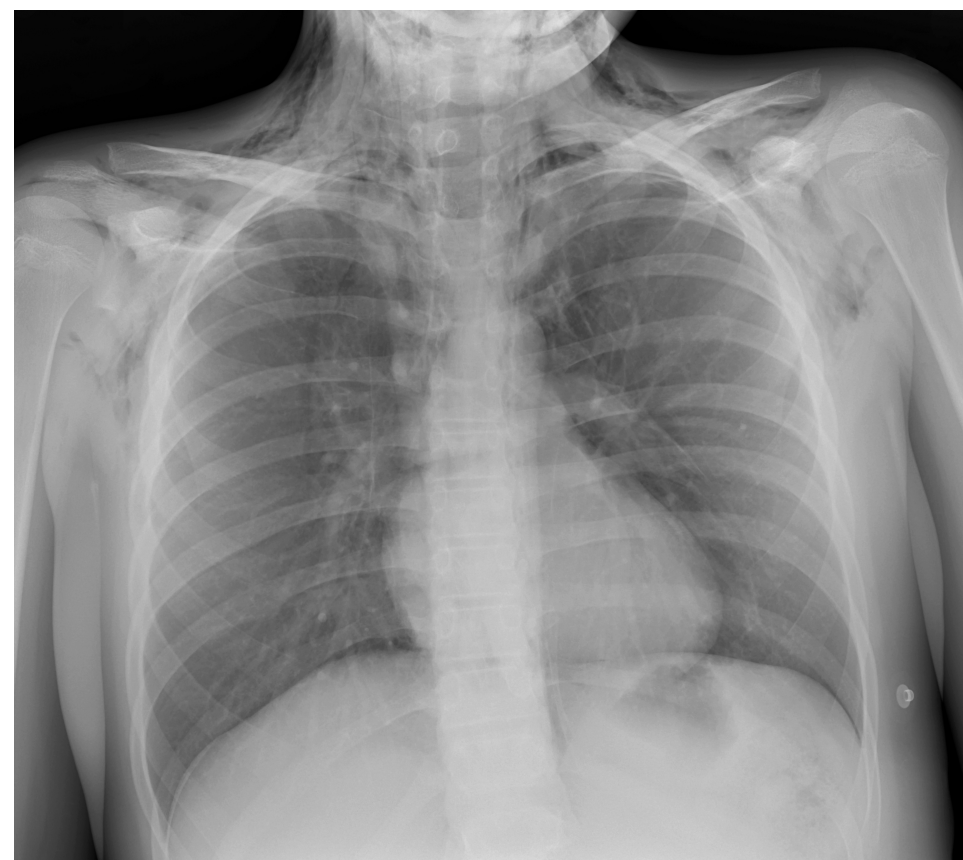

Figur 1 Røntgen thorax viste pneumomediastinum og utbredt bløtvevsemfysem over hals og øvre thorax og mulig pneumothorax.

Tre timer etter ankomst var acidosen i bedring. Respirasjonen var mindre forsert, og pasienten virket ikke lenger forvirret. Han klaget over smerter midt i brystet, var nakkestiv og klarte ikke å bøye haken ned mot brystet, men hadde ikke hodepine. Hevelsen i ansikt hadde gått noe tilbake, og han klarte nå å åpne høyre øye. Det ble tatt CT thorax (figur 2), som bekreftet pneumomediastinum, bløtvevsemfysem og luft rundt begge lunger, men ikke kollapset lunge som ved pneumothorax. Ved regranskning så man en mulig rift ved høyre hovedbronkus' avgang helt inne ved carina. Det var ingen fri væske i mediastinum. Det var ekstradural luft i spinalkanalen i hele torakalsegmentet og undersøkte cervikalavsnitt.

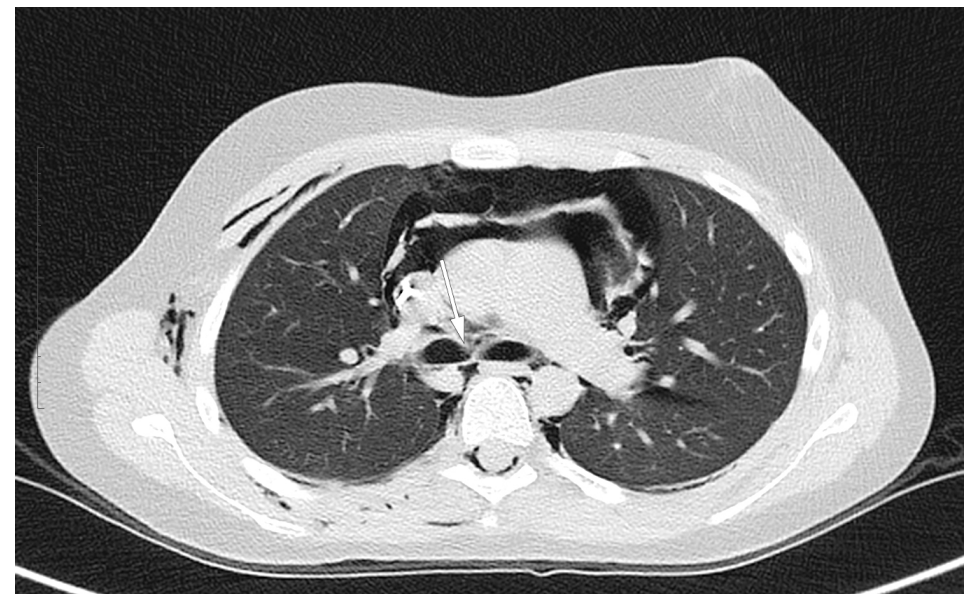

Figur 2 CT thorax lavdose uten kontrastmiddel, transversalsnitt i lungevindu viste pneumomediastinum og luft intraspinalt epiduralt (i hele volumopptakets lengde). Det var luft rundt lungene bilateralt, utenfor den ytre pleura. Lungene viste ingen tegn til sammenfall, men det var en smal rift ved høyre hovedbronkus' avgang ncer carina (pil). 
Man vurderte om det kunne foreligge øsofagusruptur som følge av oppkast og konfererte derfor med gastrokirurg. CT ga ingen mistanke om mediastinitt, og pasienten var afebril med vedvarende lav CRP. Han fikk bredspektret antibiotika profylaktisk, men man avsto fra gastroskopi. På grunn av luft i spinalkanalen konsulterte man nevrokirurg, som også anbefalte konservativ tilnærming.

Dagen etter innleggelsen var acidosen tilnærmet korrigert. To dager senere var hevelsen i ansiktet gått tilbake, og han var ikke lenger nakkestiv. Etter åtte dager på sykehus kunne pasienten reise hjem. Han hadde da fått opplæring i behandling av diabetes, allmenntilstanden var god og det var ingen kliniske tegn til bløtvevsemfysem.

\section{Diskusjon}

Vår pasient hadde nyoppdaget diabetes med alvorlig ketoacidose. I tillegg hadde han en sjelden komplikasjon med luftlekkasje fra sentrale luftveier, som ga pneumomediastinum, bløtvevsemfysem og luft i spinalkanalen.

Pneumomediastinum kan oppstå spontant eller som følge av traume. Pasientens anamnese inneholdt ikke noe kjent traume. Spontan pneumomediastinum hos barn kan være en komplikasjon til flere vanlige tilstander (2). Vanligst er astmaeksaserbasjon, etterfulgt av nedre luftveisinfeksjon (2). Andre eksempler er oppkast, øsofagusruptur og ketoacidose. Ved øsofagusruptur vil surt mageinnhold gi risiko for mediastinitt. Luft i spinalkanalen er beskrevet som en sjelden tilleggskomplikasjon til pneumomediastinum (3).

Diabetes mellitus hos barn debuterer med svært variabel presentasjon (4), hvilket kan forsinke diagnosen. Vanlige symptomer er slapphet, kvalme/oppkast og magesmerter, som kan tilskrives andre tilstander ved første legekontakt. Andre har kun respirasjonsbesvær (4). $\emptyset \mathrm{kt}$ tørste og hyppig vannlating kan skille tilstanden fra for eksempel gastroenteritt (4).

Forekomsten av diabetisk ketoacidose, og særlig alvorlig ketoacidose, er markant høyere i Norge enn i Skandinavia for øvrig. I Norge sees alvorlig ketoacidose hos 7,1\% av pasienter med nyoppdaget diabetes, mot 1,7\% i Danmark (5). Årsaken til dette er ukjent. Å være oppmerksom på diabetes som differensialdiagnose er viktig for å stille diagnosen tidlig. Vår pasient hadde atypiske tilleggsfunn som kunne forsinke diagnosen. Ved uavklarte tilstander hos barn bør det være lav terskel for å måle blodsukker.

\section{LITTERATUR:}

1. Bangstad H. Diabetisk ketoacidose (DKA). Helsebiblioteket, Akuttveileder i pediatri.

http://www.helsebiblioteket.no/retningslinjer/akuttveileder-i-pediatri/endokrinologi/diabetisk-ketoa cidose Lest 12.7.2018.

2. Chalumeau M, Le Clainche L, Sayeg N et al. Spontaneous pneumomediastinum in children. Pediatr Pulmonol 2001;31: 67-75. [PubMed][CrossRef]

3. Colavita L, Cuppari C, Pizzino MR et al. Pneumomediastinum, subcutaneous emphysema and pneumorrhachis in asthmatic children. J Biol Regul Homeost Agents 2016; 30: 585-8. [PubMed]

4. Bangstad H. Diabetes, nyoppdaget. Helsebiblioteket, Akuttveileder i pediatri. https://www.helsebiblioteket.no/pediatriveiledere?menuitemkeylev1 $=6747$ menuitemkeylev $2=6508$ $\&$ key $=151234$ Lest 12.7.2018.

5. Skrivarhaug T, Drivvoll AK, Kummernes SJ et al. Diabetic ketoacidosis (DKA) at presentation of childhood-onset type 1 diabetes (T1D) in the Nordic countries in 2010-2014-data from the Danish (DanaKid), Iceland, Norwegian (NCDR) and Swedish (Sweadiabkids) nationwide, childhood diabetes registries. Pediatr Diabetes 2017; 18 (suppl S25): 29. 
(ㅇ) Tidsskrift for Den norske legeforening 2020. Lastet ned fra tidsskriftet.no 